\title{
RATES OF CALCIUM, YIELD AND QUALITY OF SNAP BEAN
}

\author{
Simone Palma Favaro*; José Antônio Braga Neto²; Hideaki Wilson Takahashi³; Édison \\ Miglioranza ${ }^{3}$; Elza Iouko Ida ${ }^{4}$ \\ ${ }^{1}$ UCDB/Biotecnologia, C.P. 100 - 79117-900 - Campo Grande, MS - Brasil. \\ ${ }^{2}$ UFMS - Depto. de Tecnologia de Alimentos, C.P. 549 - 79070-900 - Campo Grande, MS - Brasil. \\ ${ }^{3}$ UEL - Depto. de Tecnologia de Alimentos e Medicamentos, C.P. 6001 - 86051-990 - Londrina, PR - Brasil. \\ ${ }^{4} U E L$ - Depto. de Agronomia. \\ *Corresponding author <simone@acad.ucdb.br>
}

\begin{abstract}
Calcium ions (Ca) play an important role in many biochemical processes, delaying senescence and controlling physiological disorders in fruits and vegetables. The objective of this experiment was to analyze the effect of increasing calcium concentrations in snap beans. Snap bean cultivar UEL 1 was sown in sand containing $80 \mathrm{mg} \mathrm{L}^{-1}$ of calcium supplemented with nutrient solution, plus calcium at different contents: $0,75,150$ and $300 \mathrm{mg} \mathrm{L}^{-1}$. Ca was mainly recovered in the shoots, followed by roots and pods. Calcium concentrations in the pods were 130, 259, 349 and $515 \mathrm{mg} 100 \mathrm{~g}^{-1}$ dry matter on a dry weight basis, in relation to the enhancement of calcium contents in the nutrient solution, respectively. A negative relationship between nitrogen content in the pods and calcium concentration in the nutrient solution was observed. Pods from plants grown in a solution without Ca presented necrosis in their apical region. Dieback of roots, shoots and young leaves also occurred under low calcium supply. Dry matter of pods, roots and shoots, number of pods per plant, pod weight and pod length increased proportionally to calcium concentration in solution. Increasing rates of calcium improved biomass production in snap bean cultivar UEL 1.
\end{abstract}

Key words: Phaseolus vulgaris L., biomass production, pod, nutrient solution, nitrogen

\section{DOSES DE CÁLCIO, RENDIMENTO E QUALIDADE DE FEIJÃO VAGEM}

\begin{abstract}
RESUMO: Os íons cálcio apresentam importante papel em muitos processos bioquímicos, retardando a senescência e controlando desordens fisiológicas em frutas e hortaliças. O objetivo deste experimento foi analisar o efeito de concentrações crescentes de cálcio em feijão vagem. A cultivar UEL 1 foi semeada em areia grossa contendo $80 \mathrm{mg} \mathrm{L}^{-1}$ de cálcio suplementada com solução nutritiva, acrescida dos seguintes teores de cálcio 0, 75, 150 e $300 \mathrm{mg} \mathrm{L}^{-1}$. A maior concentração de cálcio foi observada na parte aérea (ramos + folhas), seguida das raízes e, por fim, as vagens. A quantidade de cálcio nas vagens foi de 130, 259, 349 e $515 \mathrm{mg} 100 \mathrm{~g}^{-1}$ matéria seca, respectivamente da menor para a maior dose de cálcio aplicada. Observou-se relação negativa entre a concentração de nitrogênio nas vagens e o teor total absorvido em função do aumento na quantidade de cálcio da solução nutritiva. Plantas cultivadas em solução nutritiva isenta de cálcio, apresentaram necrose da porção apical das vagens e morte apical de raízes, ramos e folhas jovens. A quantidade de matéria seca de vagens, raízes e parte aérea, número de vagens por planta, massa de vagens e comprimento de vagens aumentou proporcionalmente à maior disponibilidade de cálcio na solução nutritiva aplicada. O cultivo em maiores doses de cálcio proporcionou aumento da biomassa produzida pelas plantas de feijão vagem cv. UEL 1.

Palavras-chave: Phaseolus vulgaris L., produção de biomassa, vagens, solução nutritiva, nitrogênio
\end{abstract}

\section{INTRODUCTION}

Calcium ions (Ca) play an important role in several biochemical processes (Poovaiah, 1985; 1993). Many physiological disorders in storage organs are related to low calcium content in plant tissues (Bangerth, 1979). Calcium has been described as essential for the maintenance of cell membranes and walls because it takes part in links with pectic substances which help cell to cell adhesion (Hepler \& Wayne, 1985). McKently et al. (1982) worked with snap beans grown without calcium, and they observed an $80 \%$ decrease in plant growth and 90\% reduction in the pod number. They suggested that this effect was due to low calcium mobility in vegetal tissues. Pomper \& Grusak (2004) showed no difference in pod transpiration rate and in whole-shoot Ca influx between Hystyle and Labrador cultivars which exhibit high and low pod $\mathrm{Ca}$ 
levels, respectively, otherwise a higher whole-plant water uptake was observed in Labrador, what suggested a dilution of Ca concentration in the xylem stream and thus less total Ca was transported to developing pods, relative to that in Hystyle. A wide review was made by Saure (2005) on the transport of calcium to fleshy fruits, and the author ascertained that the enhancement of gibberellin levels during periods of vigorous growth could be responsible for the often-observed decline in the course of Ca uptake during fruit development.

Besides the role of calcium in crop and human nutrition, this element is relevant for quality at post harvest (Sams, 1999) and cooked products (Ng \& Waldron, 1997). Van Buren \& Peck (1963) and Fávaro \& Ida (1998) reported that higher calcium levels in the nutrient solution resulted in firmer fresh and canned pods of snap beans. Chang et al. (1996) showed that calcium or magnesium bridges between the free carboxyl groups of adjacent pectin molecules, resulted in increases in tissue firmness of snap bean.

This study was carried out in order to investigate the effect of increasing calcium concentrations of nutrient solutions on snap bean plants.

\section{MATERIAL AND METHODS}

Snap bean cultivar UEL 1 (Castiglioni et al., 1993), which has determined growth habit and cylindrical pods, was cultivated in clay pots with coarse sand containing naturally $80 \mathrm{mg} \mathrm{L}^{-1}$ calcium. The experiment


in a greenhouse, using two plants per pot. The treatments consisted of $\mathrm{Ca}$ concentrations of $0,75,150$ and $300 \mathrm{mg} \mathrm{L}^{-1}$ in nutrient solution. No traces of Ca were found in the distilled water used in the experiment. One liter of nutrient solution containing $\left(\mathrm{mg} \mathrm{L}^{-1}\right) 234 \mathrm{~K}, 31$ P, 48 Mg, 64 S, 210 N, 5 Fe, 0.5 Mn, 0.05 Zn, 0.02 $\mathrm{Cu}, 0.01 \mathrm{Mo}$ and $0.50 \mathrm{~B}, 354 \mathrm{Cl}$ (maximum level) was added every week to each pot. Every seven days the nutrient solution was renewed with a previously washing of the sand with distilled water. During the first week after sowing, only distilled water was applied. After this period, when the seedlings had completely emerged, nutrient solution containing $50 \%$ of the salts was added. The plants were supplied with the complete nutrient solution from the eighth day onwards. The pods were harvested 10-12 days after anthesis. Ten percent of pods in all replications were sampled to measure the average length of fruits. The yield and the number of pods were quantified using all the harvested pods. Ca was extracted with $\mathrm{HCl}$ and determined by atomic absorption spectrophotometer (Miyasawa et al., 1984). Dry matter was determined drying plant parts in an oven at $105^{\circ} \mathrm{C}$, up to constant weight.
The statistical design consisted of randomized complete blocks with five replications. Each replicate was represented by ten pots, totalizing 200 units. The parametric analysis was performed using SAS (Statistical Analysis System, 1989) and data were transformed by the technique described by Box et al. (1978). SENP (Non-parametric statistical system) was used for the non-parametrical analysis (Negrillo et al., 1993). Variables following parametrical analysis were discussed by polynomial regression. All the tests were performed at a $5 \%$ significance level.

\section{RESULTS AND DISCUSSION}

At the beginning of the reproductive stage, the plants were different in height, but without apparent lesion in the meristematic regions. The low availability of calcium, mainly for the control treatment, caused dieback of shoots, young leaves and developing pods, besides necrosis in the pod tip at the last developmental stage. These deficiency symptoms have already been reported for snap beans by McKently et al. (1982), cultivar "Sprite".

\section{Calcium distribution in the snap bean plant}

Pod and root calcium concentrations (mg 100 $\mathrm{g}^{-1}$ dry matter) presented a strong positive correlation with the amount of calcium in nutrient solution, the coefficient of determination $\left(\mathrm{r}^{2}\right)$ for pods was 0.9995 and for roots 0.9994 (Figure 1). Pods grown with Ca $300 \mathrm{mg} \mathrm{L}^{-1}$ presented four times more calcium (520 mg $100 \mathrm{~g}^{-1}$ ) as compared to pods without calcium in the nutrient solution (130 mg $100 \mathrm{~g}^{-1}$ ), and the double amount was observed with the application of 75 $\mathrm{mg} \mathrm{L}^{-1}$. When snap bean was treated with $150 \mathrm{mg} \mathrm{L}^{-1}$ a proportional increase in the calcium concentration of pods was detected, as compared to pods grown with $75 \mathrm{mg} \mathrm{L}^{-1}$ of calcium, for which there was an increase

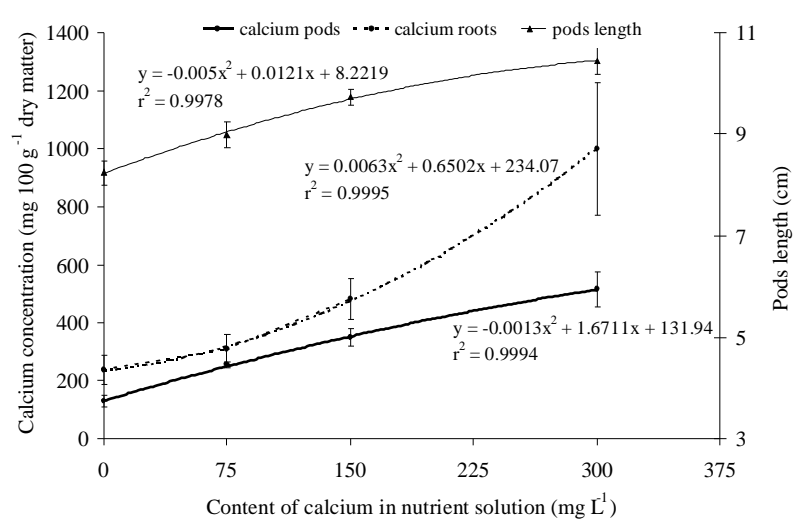

Figure 1 - Relationship between calcium amount in nutrient solution and pod and root calcium concentrations, and pod length of the snap bean cultivar UEL 1 . 
of about 37\%. Van Buren \& Peck (1963) obtained similar results for the cultivar Tendercrop. However, the $540 \mathrm{mg} 100 \mathrm{~g}^{-1}$ dry matter calcium content in the pods was attained with the addition of Ca $600 \mathrm{mg} \mathrm{L}^{-1}$ in the nutrient solution, whereas in this study a close concentration (520 mg $100 \mathrm{~g}^{-1}$ ) was observed with the application of $300 \mathrm{mg} \mathrm{L}^{-1}$. Differences in the pod calcium concentration among cultivars of snap bean were ascertained to genotype efficiency in Ca absorption (Quintana et al., 1996) and shown to be related to pod transpiration rate, stomata number and stomata size (Miglioranza et al., 2003).

A similar tendency of a higher accumulation of calcium was observed in the roots of snap bean (Figure1). Calcium amounts ranged from 240 (Ca 0

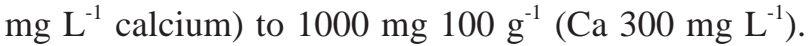
The control and $75 \mathrm{mg} \mathrm{L}^{-1} \mathrm{Ca}$ treatments had lower Ca levels. Calcium concentration in the shoot (leaves and stems) was crescent according to the availability of calcium in the nutrient solution (Table 1). The double of the calcium amount in the nutrient solution corresponded to a double increase in shoot calcium concentration. Due to the great data variability $(\mathrm{CV}=$ $31.08 \%$ ), only differences between calcium concentration of shoot from control (180 mg $\left.100 \mathrm{~g}^{-1}\right)$ and 300 $\mathrm{mg} \mathrm{L}^{-1}$ (1840 mg $100 \mathrm{~g}^{-1}$ ) were observed.

Shoots accumulated more Ca, followed by roots and pods, except for the control, where the highest calcium concentration was observed in the roots. Tagliavini et al. (2005) observed a similar distribution of calcium contents in parts of strawberry plants. According to Ascencio (1987) this higher accumulation of Ca in the shoots, and lower in the fruits, is a result of the low mobility of this ion in the phloem, leading to a consequently reduced translocation through the plant.

The cause of low Ca mobility in plant tissues is related to its insolubility due to the formation of calcium oxalate salts which precipitate usually in the phloem before reaching the fruit (Carolus, 1975 and

Table 1 - Calcium concentration in shoot (leaves and stems) of the snap bean cultivar UEL 1 grown with increasing calcium concentrations.

\begin{tabular}{lc}
\hline $\begin{array}{l}\text { Calcium concentration in nutrient } \\
\text { solution }\end{array}$ & Ca shoot* \\
\hline $\mathrm{mg} \mathrm{L}^{-1}$ & $\mathrm{mg} 100 \mathrm{~g}^{-1}$ dry matter \\
0 & $180 \mathrm{~b}$ \\
75 & $900 \mathrm{ba}$ \\
150 & $400 \mathrm{ba}$ \\
300 & $1840 \mathrm{a}$ \\
\hline $\mathrm{CV}(\%)$ & 31.08 \\
\hline
\end{tabular}

*Vertically distinct letters indicate a difference $(P<0.05)$ by the non-parametric analysis.
Marschner, 1974). The citrate quelating action might also contribute to block the calcium flow in the vascular system (Evans \& Troxler, 1953). The respiration rate in different organs is another important factor affecting calcium distribution in the plant. The leaves, because of their larger surface area, consequently a greater transpiration rate, are more effective to divert calcium from the water flow than fruits, which implies in a negative effect on the calcium supply to fruits (Barber \& Ozanne, 1970).

\section{Dry matter yield}

A general tendency of higher amounts of dry matter was detected along with increasing calcium concentrations in the nutrient solution, for all parts of snap bean plants (Table 2). However, dry weight of pods showed a difference only between levels 0 and 300 $\mathrm{mg} \mathrm{L}^{-1}$ of calcium. There was a difference between control and rates of 150 and $300 \mathrm{mg} \mathrm{L}^{-1}$ for dry weight of shoot and root.

The increase in dry matter caused by higher doses of calcium in the solution is related to a synergistic effect in the uptake of other nutrients (Fenn et al., 1987). These authors showed a positive correlation between the absorption of total $\mathrm{K}$ and $\mathrm{NH}_{4}$ with the increase of available calcium and ascertained that this is due mainly to $\mathrm{NH}_{4}$ accumulation.

There was a negative relationship between the $\mathrm{N}$ concentration and calcium availability, whereas the absorbed $\mathrm{N}$ total increased simultaneously with calcium rates (Figure 2). This result indicates a dilution effect, due to the greater production of both fresh and dry matter (Tables 2 and 3). This supposition was also reported by Fenn et al. (1987) and Takahashi (1989), who observed similar behavior for $\mathrm{N}$ uptake in plant tissue due

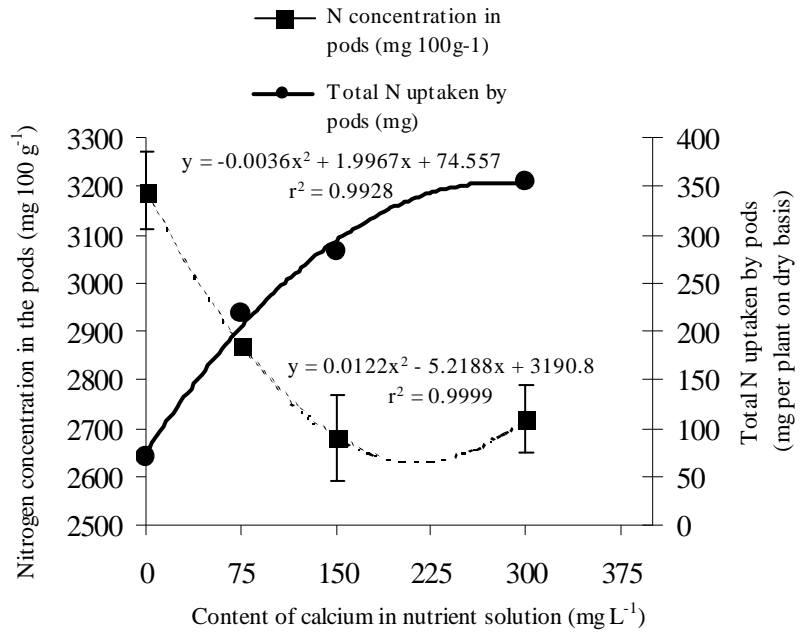

Figure 2 - Relationship between the nitrogen concentration and total nitrogen present in pods of snap bean cultivar UEL 1, grown with increasing concentrations of calcium. 
Table 2 - Dry matter yield of pods, shoot (leaves and stems) and roots from snap bean cultivar UEL 1 grown with increasing calcium concentrations.

\begin{tabular}{lccc}
\hline $\begin{array}{l}\text { Calcium concentration in } \\
\text { nutrient solution }\end{array}$ & Pods* & Shoot* & Roots* \\
\hline $\mathrm{mg} \mathrm{L}^{-1}$ & $2.18 \mathrm{~b}$ & $4.61 \mathrm{~b}$ & $1.58 \mathrm{~b}$ \\
0 & $7.59 \mathrm{ba}$ & $8.64 \mathrm{ba}$ & $2.87 \mathrm{ba}$ \\
75 & $10.58 \mathrm{ba}$ & $10.56 \mathrm{a}$ & $3.41 \mathrm{a}$ \\
150 & $13.00 \mathrm{a}$ & $12.84 \mathrm{a}$ & $3.68 \mathrm{a}$ \\
300 & 5.61 & 15.85 & 14.82 \\
\hline $\mathrm{CV}(\%)$ & &
\end{tabular}

*Vertically distinct letters indicate a difference $(P<0.05)$ by the non-parametric analysis.

Table 3 - Pod yield and quality of snap bean cultivar UEL 1 grown with increasing calcium concentrations.

\begin{tabular}{lcccc}
\hline Calcium concentration in & \multicolumn{2}{c}{ Yield } & & Quality \\
\cline { 2 - 3 } nutrient solution & fresh weight* & pod number* & weight per pod* \\
\hline $\mathrm{mg} \mathrm{L}^{-1}$ & g per plant & per plant & g \\
0 & $26.32 \mathrm{~b}$ & $7.41 \mathrm{~b}$ & $3.55 \mathrm{~b}$ \\
75 & $77.00 \mathrm{ba}$ & $20.55 \mathrm{ba}$ & $3.75 \mathrm{ba}$ \\
150 & $113.25 \mathrm{ba}$ & $28.39 \mathrm{ba}$ & $3.99 \mathrm{a}$ \\
300 & $142.59 \mathrm{a}$ & $31.65 \mathrm{a}$ & $4.51 \mathrm{a}$ \\
\hline $\mathrm{CV}(\%)$ & 5.91 & 6.38 & 3.58 \\
\hline
\end{tabular}

*Vertically distinct letters indicate a difference, $(P<0.05)$ by the non-parametric analysis.

to calcium nutrition. Shoots of petunia plants presented a decrease in the concentration of $\mathrm{N}, \mathrm{P}$ and $\mathrm{Mg}$ in response to greater applications of Ca (Frett et al., 1985).

The second order models provided by the regression analysis between the variables rates of calcium in the nutrient solution and the $\mathrm{N}$ concentration in the pods $\left(r^{2}=0.999\right)$, and between rates of calcium in the nutrient solution and the total $\mathrm{N}$ uptake by pods $\left(r^{2}=0.993\right)$, explained almost $100 \%$ of the common variation between these variables.

\section{Pod yield and quality}

The yield was deeply affected by calcium supply, although for fresh weight and number of pods per plant there were differences only between $\mathrm{Ca}$ at 0 and $300 \mathrm{mg} \mathrm{L}^{-1}$ (Table 3). Fresh weight was $193 \%$ higher when calcium was added to the nutrient solution at 75 $\mathrm{mg} \mathrm{L}^{-1}$ as compared to the control. Supplying snap bean with $150 \mathrm{mg} \mathrm{L}^{-1}$, the fresh weight had an improvement of $47 \%$, and this yield reached a higher value of $85 \%$ with $300 \mathrm{mg} \mathrm{L}^{-1}$. These achievements may represent an important improvement in the commercial production, leading to better income.

The aspects related to the quality of pods were also improved by a greater availability of calcium in the nutrient solution. The averages of pod length increased according to the higher availability of calcium, following a second order model that showed a good correlation with $r^{2}=0.9978$ (Figure 1). The average pod length increased $26.21 \%$ at $300 \mathrm{mg} \mathrm{L}^{-1}$ Ca concentration in comparison to the control. The weight per pod ranged from $3.55\left(0 \mathrm{mg} \mathrm{L}^{-1}\right)$ to $4.51 \mathrm{~g}$ (300 $\mathrm{mg} \mathrm{L}^{-1}$ ), and the control differed from rates 150 and $300 \mathrm{mg} \mathrm{L}^{-1}$ (Table 3).

\section{CONCLUSION}

For all calcium levels tested in cultivar UEL 1 , there is a direct relation between increasing calcium concentration and yield, weight and length of pods improvement. Most of the absorbed calcium was accumulated by the shoot, followed by roots and pods. The increment of calcium in the pods was followed by an increase in the level of absorbed total $\mathrm{N}$; however, the concentration was reduced, probably due to the dilution effect promoted by the higher dry matter yield.

\section{REFERENCES}

ASCENCIO, J. Potassium and calcium distribution patterns along the leaf insertion gradient of bean plants grown in nutrient solutions. Journal of Plant Nutrition, v.10, p.455-484, 1987.

BANGERTH, F. Calcium-regulated physiological disorders of plants. Annual Review of Phytopathology, v.17, p.97-122, 1979.

BARBER, S.A.; OZANNE, P.G. Autoradiographic evidence for the differential effect of four plant species in alterning the calcium content of rhizosphere soil. Soil Science Society of America Proceedings, v.34, p.635-637, 1970.

BOX, G.E.P.; HUNTER, W.G.; HUNTER, J.S. Statistics for experimenters. New York: John Wiley \& Sons, 1978. 653p. 
CAROLUS, R.L. Calcium relationships in vegetable nutrition and quality. Communications in Soil Science and Plant Analysis, v.6, p.285-298, 1975.

CASTIGLIONI, F.V.B.R.; TAKAHASHI, L.S.A.; ATHANAZIO, J.C.; MENEZES, J.R.; FONSECA, M.A.; CASTILHO, S.R. "UEL 1": nova cultivar de feijão-vagem com hábito de crescimento determinado. Horticultura Brasileira, v.11, p.164, 1993.

CHANG, C.Y.; LIAO, H.J.; WU, T.P. Relationships between the textural changes and the contents of calcium, magnesium ions, and non-freezing water in the alcohol-insoluble solids of snap bean pods during cooking processes. Food Chemistry, v.55, p.49-53, 1996.

EVANS, H.J.; TROXLER, R.V. Relation of calcium nutrition to the incidence of blossom-end-rot in tomatoes. Proceedings of the American Society for Horticultural Science, v.61, p.346352, 1953.

FÁVARO, S.P.; IDA, E.I. Textura de feijão-vagem (Phaseolus vulgaris L) processado ou não: efeito da aplicação de concentrações crescentes de cálcio via absorção radicular. Ciência e Tecnologia de Alimentos, v.18, p.188-192, 1998.

FENN, L.B.; TAYLOR, R.M.; HORST, G.L. Phaseolus vulgaris growth in an ammonium-basisd nutrient solution with variable calcium. Agronomy Journal, v.79, p.89-91, 1987.

FRETT, J.J.; DIRR, M.A.; ARMITAGE, A.M. Nitrogen and calcium nutrition of Petunia $\times$ hybrida 'Coral Sea'. Scientia Horticulturae, v.26, p.351-359, 1985.

HEPPLER, P.K.; WAYNE, R.O. Calcium and plant development. Annual Review of Plant Physiology, v.36, p.397-439, 1985.

MARSCHNER, N.G. Calcium nutrition of higher plants. Netherlands Journal of Agricultural Science, v.22, p.275282, 1974.

McKENTLY, H.A.; GARDNER, F.P.; SCHRODER, V.N. Effects of calcium and potassium deficiencies on the growth and development of bean (Phaseolus vulgaris L.) in nutrient culture. Soil and Crop Science Society of Florida Proceedings, v.41, p.139-144, 1982.

MIGLIORANZA, E.; ARAÚJO, R.; ENDO, R.M.; SOUZA, J.R.P.; MONTANARI, M. A. Teor de cálcio em frutos de diferentes cultivares de feijão-vagem. Horticultura Brasileira, v.21, p.159-162, 2003.

MIYASAWA, M.; PAVAN, M.A.; BLOCK, M.F.M. Determination of $\mathrm{Ca}, \mathrm{Mg}, \mathrm{K}, \mathrm{Mn}, \mathrm{Cu}, \mathrm{Zn}, \mathrm{Fe}$, and $\mathrm{P}$ in coffee, soybean, corn, sunflower, and pasture grass leaf tissues by a $\mathrm{HCl}$ extration method. Communications in Soil Science and Plant Analysis, v.15, p.141-147, 1984.
NEGRILLO, B.G.; SARRIES, G.A.; ZACARIAS, M.; ALVES, M.C.; OLIVEIRA, J.C.V. SENP - Sistema de estatística nãoparamétrica. Piracicaba: CIAGRI/USP, 1993.

NG, A.; WALDRON, K.W. Effect of cooking and pre-cooking on cell-wall chemistry in relation to firmness of carrot tissues. Journal of the Science of Food and Agriculture, v.73, p.503-512, 1997.

POMPER, K.W.; GRUSAK, M.A. Calcium uptake and whole-plant water use influence pod calcium concentration in snap bean plants. Journal of the American Society for Horticultural Science, v.129, p.890-895, 2004.

POOVAIAH, B.W. Role of calcium and calmodulin in plant growth and development. Hortscience, v.20, p.347-352, 1985.

POOVAIAH, B.W. Biochemical and molecular aspects of calcium action. Acta Horticulturae, n.326, p.139-147, 1993.

QUINTANA, J.M.; HARRISON H.C.; NIENHUIS, J.; PALTA J.P.; GRUSAK, M.A. Variation in calcium concentration among sixty $\mathrm{S}_{1}$ families and four cultivars of snap bean (Phaseolus vulgaris L.). Journal of the American Society for Horticultural Science, v.121, p.789-793, 1996.

SAMS, C.E. Preharvest factors affecting postharvest texture. Postharvest Biology and Technology, v.15, p.249-254, 1999.

SAURE, M.C. Calcium translocation to fleshy fruit: its mechanism and endogenous control. Scientia Horticulturae, v.105, p.6589, 2005.

STATISTICAL ANALYSIS SYSTEM. SAS/STATâ User's guide. 4.ed. Cary, 1989. v.2.

TAGLIAVINI, M.; BALDI, E.; LUCCHI, P.; ANTONELLI, M.; SORRENTI, G.; BARUZZI, G.; FAEDI, W. Dynamics of nutrients uptake by strawberry plants (Fragaria $\times$ Ananassa Dutch.) grown in soil and soilless culture. European Journal of Agronomy, v.23, p.15-25, 2005.

TAKAHASHI, H.W. Relação Ca:Mg:K no desenvolvimento, produção, composição mineral e distúrbios fisiológicos relacionados com o cálcio em tomateiro (Lycopersicon esculentum, Mill). Piracicaba: USP/ESALQ, 1989. 167p. (Tese - Doutorado).

VAN BUREN, J.P.; PECK, N.H. Effect of calcium level in nutrient solution on quality of snap bean pods. Proceedings of the American Society for Horticultural Science, v.82, p.316, 1963.

Received December 20, 2005

Accepted June 22, 2007 